\title{
The Role of Islamic Values to Prevent The Society for Cyber Crime Victim in Social Media
}

\author{
Edy Santoso \\ Postgraduate program of Business Law \\ Islamic University of Nusantara \\ Bandung, Indonesia \\ edysantoso197@gmail.com
}

\begin{abstract}
Along with the increasing use of Information and Communication Technology (ICT) as a tool for human interaction, the development of communication is growing. The use of this tool to becomes a trigger for changing of human interaction in all sectors, whose implications could be either positive or negative. However, it needs to watch out for negative impact because the trend of crime in cyberspace cases shows a significant increase. Legal problem on cyber crime could be fraud and identity theft through social media. As an example in 2016, police of Indonesia has handled about 1,627 cases, whereby as many as 1,207 is a cyber crime cases. While, in 2017 as many as $\mathbf{1 , 7 6 3}$ cyber crime cases. In this regards, the use of ICT for activities in social media with a religious approach is expected to provide influence to the community what is could and could not be done.
\end{abstract}

Keywords-religious approach; social media; cyber crime; Islamic law

\section{INTRODUCTION}

Nowdays, Information and Communication Technologies (ICT) has an important role in the development of communication media. It have become indispensable tools, allowing the use of massive information storage, processing, dissemination, searching and retrieval [1]. Previously many people who rely on the use of telephones in communicating, then slowly gradually has grown to use smartphone for chatting by text. It allows sharing information in the form of text, pictures and video to many people rapidly. These forms of information are then very influential on public opinion to take decision. Most people rarely investigation whether this information is right or wrong. Here, Mary Cross said, "We are already experiencing the cultural effects of the digital revolution that is underway" [2].

Cyber crime victims can occur due to victims of financial fraud and victims of identity theft in the social sphere. Cyber crime is one part of a crime committed by using electronic media through Internet access. In this case, use of ICT is going to provide facility not only have a positive impact, but also have a negative impact. Here, ICT is a "tool" that provides convenience for humans. Thus, the users itself who really determine the usefulness of ICT. Here, use of ICT in social media, this will be greatly influenced by the user's intentions.
Internet user has play an important role in using of social media in society. Ease of accessing social media through the use of the Internet becomes the main point which determines "many" or "few" of internet users. Referring to research report of Association of Internet Service Providers Indonesia (APJII), Internet users in Indonesia from year to year experienced a very significant increase. Internet users in 2015 amounted to 10.2 million people. By 2016, that number has increased to 132.7 million people. While the data in 2017 showed an increase to 143.26 million people [3].

Referring to the number of Internet users mentioned above, as many as $87.13 \%$ are users of social media [4]. With regard to security, the survey results show that $65.98 \%$ of the public are aware that the data can be retrieved, and as many as $83.98 \%$ of them are aware of the risks associated with fraud on the Internet[5]. However, in practice, many communities become victims. The use of social media raises legal issues in the field of cyber crime could be related to fraud and identity theft. In 2016, police of Indonesia has handled about 1,627 crime cases, whereby as many as 1,207 is a cyber crime cases. [6] In 2017, cases of cyber crime have increased. In this case, the Police handled as many as 1,763 cyber crime cases [7]. Therefore, discussions related to the negative impacts of social media use become very important.

Paying close attention to any information gained in social media, whether through WhatsApp, Facebook, Line, and others requires the maturity of thinking and emotional control that taught in Islam. In this case, religion has an important role related to the understanding of law and ethics in the use of social media, so that the cyber crime will be prevented. Therefore, this paper will identify the violations of cyber crime that focus on fraud and identity theft activities in social media, and examine the role of Islamic values to discuss an effort to prevent the society to become a cyber crime victim in social media.

\section{RESEARCH METHOD}

This paper uses qualitative empirical legal research with multidisciplinary research approach through the analysis of legal rules under Law No.11 of 2008 on Electronic information and transactions (EIT Law), and Islamic Values. The data used are secondary data from various valid sources, such as the 
Indonesian National Police, and the Association of Internet Service Providers Indonesia (APJII).

\section{RESULT AND DISCUSSION}

As a preventive effort for people not to become victims of cyber crime in social media, the understanding of religious values is expected to have a very significant effect. In Islam, the process of interaction between individuals or groups associated with hablun minannaas (relationships among humans). It is a part of Muamalah whereby the process of interaction including the manufacture (production), distribution (distribution), access (consumption), and the use of information and communication[8].

Ideally, the information related to data which should be accurate and timely, specific and organized for a purpose, presented within a context that gives it meaning and relevance, and can lead to an increase in understanding and decrease in uncertainty [9]. However, in Muamalah, many found violations associated with the delivery of information through media. Here, information is a main object of the violations of cyber crime in social media. This is because, the media not only carry the content alone, but also bring the context in it [10]. Furthermore, McLuhan expresses "the media is the message" [11]. Then, misunderstanding the information, it would be wrong to take action.

Social media is primarily internet or cellular phone based applications and tools to share information among people [12]. While, the information that can be shared in the form of posts, pictures, photos, videos and so forth. Here, social media is the collective of online communications channels dedicated to community-based input, interaction, content-sharing and collaboration [13]. If observed, McLuhan's opinion here, this social media that has the power to deliver messages that can change the mindset, culture and decisions of its users. However, talking about social media is to talk about individual relationships with media devices [14].

\section{A. Cyber Crime on Fraud and Identity theft in Social Media}

The high Internet user of social media in Indonesia, is resulted in the number of cases of cyber crime increased. While, social media also offers a number of features that criminals may find attractive [15]. In this situation, fraudsters can use social media in their efforts to appear legitimate, to hide behind anonymity, and to reach many people at low cost [16].

Cybercrime is defined as a crime in which a computer is the object of the crime (hacking, phishing, spamming) or is used as a tool to commit an offense (child pornography, hate crimes) [17]. The connection with social media is that cyber criminals may use computer technology to access personal information, business trade secrets or use the internet for exploitive or malicious purposes [18].

In this regards, criminals can also use computers for communication and document or data storage. The use of ICT will cause disadvantage related to the potential for invasion of privacy and security risks [19]. Identity theft is the unauthorized access to personal information or documents; while identity fraud is a crime involving the use of false identity [20]. In this regards, authors identify the most social media users commit violations related to the fraud and identity theft including as follows:

1) Quiz feature: Fraud can be through the quiz feature, like the one on face book. However, some quiz features will request access to the user profile. Things to look out for that feature will ask some more questions about the user's personal data. Simply put: every quiz offered to you on Facebook is ruse to get your personal data and perpetuate the quiz. These quizzes are designed by advertising agencies, not psychometricians. They evaluate nothing but how vulnerable you are to bogus quizzes [21].

For the users who are not aware that this fraudulent attempt to obtain a user's personal identity will answer honestly all the questions. This rare is the beginning of the process of fraud occurs. Through user responses, the offender can access user accounts and retrieve identity data that can be used to commit other fraud.

This act is very contrary to the rules in Article 30 (2) Law No.11 of 2008 on Electronic information and transactions (EIT Law) related to governing on knowingly and without authority or unlawfully accesses Computers and/or Electronic Systems in any manner whatsoever with the intent to obtain Electronic Information and/or Electronic Records. In Islam, retrieve identity data with unjustly (dhalim) is called "Ghasb". Refer to Al Qur'an (QS. An Nisaa': 29) that it is prohibits from illegally acquiring each other's property using various dishonest.

2) Free gift: Another form of a fraud is through the giving of free gifts. Many users are easily tempted by the giveaway. The user will immediately hover over the 'Sign me up!' link to get it. This could be the user's initial process will be deceived. Giveaway offers an Ipad gift, airline ticket, or free jewelry promised by most companies. In practice, this scam abuses brand names and logos of well-known companies and products in order to make the offers look legitimate [22].

In this regards, easy terms like signing up for a newsletter or purchasing a company's product will make the user go crazy and easily provide his or her personal data. Therefore, keep your personal details information. In this case requires the user's own caution for what information you share and post on social networking sites. This case also has same risk that offender can unlawfully accesses Computers and/or Electronic Systems to obtain Electronic Information as regulated in Article 30 (2) of EIT Law.

3) Fundraising: Fraud can also take advantage of certain social moments associated with charitable activities to help the victim. Here, social media has become an important and effective tool in many fundraising efforts [23]. The really dangerous thing is the charity link can contain malware virus on the user's computer. In addition, charity donations will not make it to the victims. The perpetrator of the fraud will use the money it collects for its own sake. Fraud and identity theft become a very powerful two-edged sword associated with social charity activities. 
In this regards, Indonesia has regulated about the issue in article 28 (1) of EIT Law that said "Any Person who knowingly and without authority disseminates false and misleading information resulting in consumer loss in Electronic Transactions. In Islamic law, Allah would not grace with His guidance one who has wasted his own self by Lying [about Him] (QS. Al-Mu'min': 28).

4) Friendship: There is a brand new scam called "farcing" or "friend fraud" that criminals use to wiggle their way into your network and take large amounts of cash from your bank account [24]. Thus, be careful with friend requests. Users must be smart to choose. The thing that worries, the perpetrators of fraud will be cloning the entire face book profile of the user and creating a fake account on behalf of that person. Then, hackers can send deceptive links that contain viruses.

Here, fraudsters will use stolen data for their benefit. Face book cloning is a technique in which scammers create a fake Face book profile by using images and other information stolen from a targeted user's real Face book profile [25]. In this regards, the scammers may be able to create a profile that - at least at first glance - looks very much like the target's genuine profile. Especially if the victim has all or some of his or her profile material set to "public" [26].

This act is very contrary to the rules in Article 32 (1) of EIT Law related to governing on any person who knowingly and without authority or unlawfully in any manner whatsoever alters, adds, reduces, transmits, tampers with, deletes, moves, hides Electronic Information and/or Electronic Records of other Persons or of the public. Furthermore, this act is also unlawful of article 35 of EIT law that said "any Person who knowingly and without authority or unlawfully manipulates, creates, alters, deletes, tampers with Electronic Information and/or

Electronic Records with the intent that such Electronic Information and/or Electronic Records would seem to be authentic data.

\section{B. The Role of Islamic Values in Preventing Cyber Crime}

Islam as a religion that rahmatan lil alamin not only teaches about spiritual worship, but also teach muamalah. It contains ethical and moral pronouncements in life [27]. In digesting information, user should use a deep and logical as well as ethic thought process. Paying attention to the modus operandi used by the perpetrators of fraud and identity theft mentioned above, users should understand these things and to be careful of any news in social media so as not to be a victim of both material and in material. Considering the information shared is sometime contains hoax.

Hoax is a word used to show false news or attempts to deceive or outsmart the reader to believe. It is a trick in which someone tells people a lie [28]. In Indonesia, 2016, hoax becomes a national issue that is very worrying about society. Therefore, Indonesian Council of Ulama (Majelis Ulama Indonesia/MUI) makes fatwa against fake news in 2017. It is Fatwa of MUI No. Year 2017 regarding Law and Guidelines of Muamalah through Social Media (MUI 2017).
Although this fatwa is not binding, as legislation, but it will be widely obeyed by most Muslims. Fatwa this will be a guide in muamalah. Muslim jurists have many opinions in their life, but what makes their opinion a fatwa is that it is a response to a question addressed by a mustafti (someone who asks a fatwa) [29]. The existence of a fatwa is important, given the development of muamalah this time has been so rapid. Thus, the problem of society becomes very complex. The current cases didn't occurred in the time of Rosullulah, so it requires a fatwa.

The fatwa will provide legal certainty regarding muamalah, thus it will give guidance on Islamic values that must be obeyed. In this case, religion has a very significant role so that Islamic values can be used as guidelines for society. Furthermore, this is expected to greatly affect the activity of social media usage. In this paper, author identified some of Islamic values that are expected to prevent society to become a victim of cyber crime in social media. As a form of prevention, Islam teaches as follows:

1) Tabayyun (Investigation): Refer to fatwa of MUI No. Year 2017 that Social Media means is electronic media, which is used to participate, share, and create content in the form of blogs, social networks, forums, virtual worlds, and other forms. However, before believing what information is obtained, the user must remain vigilant and cautious, by doing tabayyun. It is important that we instil the culture of tabayyun, which is to check and verify news and information before accepting it as true. Tabayyun is especially critical if we want to share and forward information to other people [30].

It refers to QS.Al-Hujurat:6 that said "O you who have believed, if there comes to you a disobedient one with information, investigate, lest you harm a people out of ignorance and become, over what you have done, regretful". This becomes important, so that not only ourselves who become victims of cyber crime, but also the other users who get the information.

Tabayyun is the first step, which will prevent social media users to avoid all forms of cyber crime. Tabayyun has always to make it a habit to investigate with the body or person of authority regarding the issue at hand. The user should be sure, if the news or information comes from a verified source. In cyberspace activity, the user has to investigate the domain name of website that connected in the "link" provided by the information provider. Victims of cyber crime can start from a fake domain name from the original. The perpetrators of crime generally make this similar.

Most of cyber crime activities on a fraud and identity theft created a fake domain name, especially in offering Quiz feature and gift. The perpetrators, skilled in provoking questions and giving hope to the victim, so the victim emotionally did not realize that he was the target victim. The tabayyun principle taught by religion will play a role in reminding the user of the importance of conducting an earlier investigation, and providing a time lag before making a decision.

2) Mutasamih (Forbearing): One of the meaning of Mutasamih (Forbearing) is to keep oneself from doing 
something [31]. Here, patient behavior to not hastily respond to information in social media becomes one of the keys to avoid fraud attempts in social media. The offender will take advantage of this situation as a mode of searching for prey. The mode of free gift serves as a moment to force immediate users who are interested and visit the site. For users who are impatient to scrutinize the contents of the information, will soon become victims of fraud or identity theft.

As for, through the mode of friendship as well, not infrequently people are deceived to provide assistance to people who claim to be old friends. His mode by claiming to be an old friend in need of help. The hope, he or she will soon get financial assistance in accordance with the amount of money requested. Situations involving the emotions of the users become the main target of the perpetrators of crime.

This hasty nature, it is human nature to get what they want. As mentioned in Al-Isra':11 which reads" And man supplicates for evil as he supplicates for good, and man is ever hasty". Furthermore, the Prophet's hadith from Anas ibn Malik reported: forbids haste, including haste to spread information before there is clarity, as his saying "Composure is from Allah, and haste is from Satan" [32].

Mutasamih is to be an important to think over all information which user read before action. This Islamic value is very important to combat the cyber crime that generally is conducted by a hacker through user neglect. Armed of the data identity of victim, a hacker will be able to access into the social media as well as financial system, so that the perpetrator can do the crime.

3) Keep secrets: Cyber crime victims are highly dependent on the user. Personal identity and financial data are things that should be kept secret. In this case, as well as any legislation made by the government, and as well as any security system designed by service providers without user participation itself will be difficult to achieve. Persistence in maintaining important information is a key word to avoid the victims of crime in cyberspace. The user has play a important role for keeping secrets of all the important.

In this regards, the religious values of Islam forbid to tell private or other secrets to anyone. Personal identity and financial data is a very secret thing. In general, the providers of banking services will also always be reminded, so that financial data users are not disclosed to others including bank employees. In Q.S An-Nisa':58 which reads" Indeed, Allah commands you to render trusts to whom they are due ...". In this case, the service providers in social media or other services have given a mandate to not disclose confidential data. Thus, every user has responsibility to keep secrets the valuable information.

\section{CONCLUSIONS}

This paper concluded that the social media not only provide benefits, but also will provide risks related to the fraud and identity theft. Although the survey results prove that the public has been aware of these risks, but in practice the victims associated with cyber crime is showing an increase. The crime forms identified in the cyber crime domain in social media related to the fraud and identity theft are including activities on offering quiz feature, free gift, fundraising, and friendship. This crime, taking advantage of the carelessness of Internet users who put aside common sense.

Thus, the Islamic values which come from Allah are expected to remind the user to obey them. The first step is very important when receiving information is to conduct an investigation (Tabayyun) first. To conduct investigations, users are taught not to rush. It needs forbearing (Mutasamih) that it means to keep oneself from doing something for a while. The last, another important point regarding the value of Islam is to hold firm private secrets. This is an important point to avoid this cyber crime. Understanding these values, accompanied by adherence to follow it, is expected to form the good habits in addressing the information that user receives. Thus, who can guard against this crime is him or herself.

\section{ACKNOWLEDGMENT}

The author is thankful to all the staff members of agency for human resources development (BPSDM), Ministry of Law and Human Rights, Republic of Indonesia for their valuable support. The author is also thankful to Islamic University of Nusantara for supporting this study.

\section{REFERENCES}

[1] Bainbridge, David I, Introduction to Information Technology Law, Sixth Edition, Pearson Longman, England, 2008, pp.1

[2] Cross, M, Bloggerati, Twittwrati: How Blogs and Twitter are Transforming Popular Culture, Santa Barbara, California:Praeger, 2011, pp.23. See aso Rulli Nasrullah, Media Sosial, Perspektif Komunikasi, Budaya, dan Sosioteknologi, Simbiosa Rekatama Media, Bandung, 2015, pp.xi.

[3] Assosiasi Penyelenggara Jasa Internet Indonesia (APJII), 'Penetrasi dan Perilaku Pengguna Internet Indonesia', Jakarta, 2017, pp.7.

[4] Ibid, pp.32

[5] Ibid. pp. 36

[6] Mei Amelia R, "Kejahatan Cyber di Jakarta Sepanjang 2016 Mencapai 1.207 Kasus", detikNews, Jumat 30 Desember 2016, https://news.detik.com, accessed on 21 February 2018.

[7] Puteranegara Batubara, "Tahun 2017, Polisi Tangani 1.763 Kasus Kejahatan Siber", Kamis 21 Desember 2017, https://news.okezone.com, accessed on 21 February 2018.

[8] See fatwa of MUI No. Year 2017 regarding Law and Guidelines of Muamalah Through Social Media.

[9] See definition of inforarmation, http://www.businessdictionary.com, accessed on 23 February 2018.

[10] See Rulli Nasrullah, Media Sosial, Perspektif Komunikasi, Budaya, dan Sosioteknologi, Simbiosa Rekatama Media, Bandung, 2015, pp.4.

[11] McLuhan \& Fiore,Q, The Medium is message, Ginko Press, California, 2001. See also Rulli Nasrullah, Ibid, pp.4.

[12] See http://www.businessdictionary.com, accessed on 21 February 2018.

[13] See [http://whatis.techtarget.com, accessed on 21 February 2018

[14] See also Rulli Nasrullah, Op.cit, pp.4.

[15] See www.investor.gov, accessed on 21 February 2018.

[16] Ibid

[17] See https://www.techopedia.com, accessed on 21 February 2018.

[18] Ibid 
[19] Alan Davidson (2009), The Law of Electronic Commerce, Cambridge University Press, Sydney, 2009, pp. 1

[20] Sproule, S. and Archer, N. (2007), "Defining identity theft", 2007 World Congress of the Management of e-Business, IEEE Computer Society, Los Alamitos, CA, pp. 163-173. See also Norm Archer, (2011),"Consumer identity theft prevention and identity fraud detection behaviours", Journal of Financial Crime, Vol. 19 Iss: 1 pp. 20 - 36. p.21.

[21] Ben Rothke, Just say no to Facebook quizzes, AUG 7, 2017, https://www.csoonline.com/article/3214264/fraud/just-say-no-tofacebook-quizzes.html, accessed on 03 March 2018.

[22] See NN, Beware of scam gift voucher \& product offers on social networking sites, 4 November 2011, https://www.scamwatch.gov.au, accessed on 03 March 2018.

[23] See https://www.gaston.k12.nc.us, accessed on 03 March 2018.

[24] See Princess Clark, How To Protect Yourself From "Friend Fraud" In The Age Of Social Media, SEP 3, 2014, https://www.forbes.com/, accessed on 3 February 2018.
[25] See http://www.hoax-slayer.net, accessed on 23 February 2018

[26] Ibid

[27] See also Felix Pomeranz, Etichs: toward globalization, Emerald Journal, Vol.19 No. 1, 2014, pp.8

[28] See www.collinsdictionary.com, accessed on 23 February 2018.

[29] Luthfi Assaukanie, Fatwa and Vielence in Indonesia, Journal of Religion and Society, Vol.11, ISSN 1522-5658, 2009, pp.2

[30] Shaikh Mohd Saifuddeen Shaikh Mohd Salleh, 'Tabayyun' in the age of social media, Tuesday, 13 Dec 2016, https://www.thestar.com.my, accessed on 3 February 2018.

[31] See www.thefreedictionary.com, accessed on 3 February 2018.

[32] See Source:Sunan al-Kubrā 18651, https://abuaminaelias.com, accessed on 3 February 2018. 